This work is licensed under a Creative Commons Attribution 3.0 License.

Research article

urn:lsid:zoobank.org:pub:16E64AF8-518C-47F0-B3CF-6BA707C222FA

\title{
New species of Thelonema, Metasphaerolaimus, and Monhystrella (Nematoda, Monhysterida) from Kermadec Trench, Southwest Pacific
}

\author{
Daniel LEDUC \\ National Institute of Water and Atmospheric Research, Private Bag 14-901, \\ Wellington, New Zealand; +64 43860379. \\ Email: Daniel.Leduc@niwa.co.nz \\ urn:1sid:zoobank.org:author:9393949F-3426-4EE2-8BDE-DEFFACE3D9BC
}

\begin{abstract}
Three new species of the order Monhysterida are described based on specimens obtained at depths of 8081 and $9177 \mathrm{~m}$ in the Kermadec Trench. Thelonema clarki sp. nov. is characterised by a large body size (3230-4461 $\mu \mathrm{m})$, short cylindrical buccal cavity, gubernaculum without apophyses, and long conico-cylindrical tail. This is the first record of the genus since its original description over two decades ago from the Peru Basin. Metasphaerolaimus constrictus sp. nov. is characterised by a relatively long body $(1232-1623 \mu \mathrm{m})$, slightly arcuate spicules without gubernaculum, and conico-cylindrical tail with inner cuticle conspicuously thickened immediately anterior to cylindrical portion. Monhystrella kermadecensis sp. nov. is characterised by a circle of papillose outer labial sensillae slightly anterior to the four short cephalic setae, gubernaculum with caudal apophyses, the presence of distinct cuticularised piece along anterior vaginal wall, and a relatively short conical (males) or conico-cylindrical tail (females) with conical, ventrally-curved spinneret. $M$. kermadecensis sp. nov. can be differentiated from all other species of the genus, and, indeed, the entire family, based on the variable position of the anterior gonad relative to the intestine. The new species is classified within the Monhysteridae, and not the closely-related Xyalidae, based on the small body size, a smooth cuticle, and the presence of six outer labial papillae and only one testis. Further work is required to clarify the placement of M. kermadecensis sp. nov. relative to other monhysterid genera. A tabular key to all ten valid Metasphaerolaimus species is presented.
\end{abstract}

Keywords. Linhomoeidae, Sphaerolaimidae, Monhysteridae, hadal, New Zealand.

Leduc D. 2015. New species of Thelonema, Metasphaerolaimus, and Monhystrella (Nematoda, Monhysterida) from Kermadec Trench, Southwest Pacific. European Journal of Taxonomy 158: 1-19. http://dx.doi.org/10.5852/ ejt.2015.158

\section{Introduction}

The Order Monhysterida is well represented in hadal trench samples (> $6000 \mathrm{~m}$ depth), with the family Monhysteridae often dominant (Gambi et al. 2003; Vanhove et al. 2004). The families Sphaerolaimidae and Linhomoeidae are also common in hadal trench samples, but are typically much less abundant (e.g., Tietjen 1989). Whilst species of the families Sphaerolaimidae and Linhomoeidae are relatively large ( $>1$ $\mathrm{mm}$ in length) and easy to identify, species of the family Monhysteridae are typically small $(<0.8 \mathrm{~mm}$ in 
length) and often represented by many morphologically similar species in deep-sea samples (D. Leduc unpublished data). As a result, data on the distribution of Monhysteridae species in the deep sea are scarce despite their high abundance (Tietjen 1989; Miljutin et al. 2010). In addition, there has been some confusion related to the identification of the small and morphologically similar genera Monhystrella Cobb, 1918 and Thalassomonhystera Jacobs, 1987. Vanhove et al. (2004) and Gambi et al. (2003) recorded high densities of the genus Monhystera Bastian, 1865 in hadal trenches, despite a taxonomic revision by Jacobs (1987) almost two decades earlier resulting in all marine Monhystera species being transferred to either Thalassomonhystera or Monhystrella (Fonseca \& Decraemer 2008). More work is clearly needed on the taxonomy of this family, as well as other Monhysterida, in order to identify patterns in species distribution within and among trenches.

Of the fifteen nematode species so far described / recorded from hadal trench environments worldwide (Miljutin et al. 2010; Leduc 2015), three are known from Kermadec Trench: Synonchoides galathea Wieser, 1956 (4570 m depth), Manganonema rowdeni Leduc, 2015 (8081 m) and Manganonema majusculum Leduc, 2015 (8081 m). Here, three new species of the Order Monhysterida, one species each of the families Linhomoeidae, Sphaerolaimidae and Monhysteridae, are described based on specimens obtained at depths of 8081 and $9177 \mathrm{~m}$.

\section{Materials and methods}

Kermadec Trench is situated in the Southwest Pacific Ocean and is formed by the subduction of the Pacific Plate under the Indo-Australian Plate. It extends from approximately $26^{\circ}$ to $36^{\circ} \mathrm{S}$ near the northeastern tip of New Zealand's North Island. Samples were collected from the axis of Kermadec Trench at depths of 8081 and $9177 \mathrm{~m}$ during the Woods Hole Oceanographic Institute (WHOI) cruise TN309 (RV Thomas G. Thompson) in May 2014. The sediment cores were obtained using the submersible ROV Nereus (core internal diameter $=6.35 \mathrm{~cm}$ ). Cores were sliced into $0-1,1-2,2-3,3-4,4-5$ and $5-10 \mathrm{~cm}$ layers and fixed in $10 \%$ buffered formalin. Samples were rinsed on a $20 \mu \mathrm{m}$ sieve to retain nematodes. Nematodes were extracted from the remaining sediments by Ludox flotation, stained with Rose Bengal, and transferred to pure glycerol (Somerfield \& Warwick 1996). Species descriptions were made from glycerol mounts using differential interference contrast microscopy and drawings were made with the aid of a camera lucida.

All measurements are in $\mu \mathrm{m}$, and all curved structures are measured along the arc. Type specimens are held in the NIWA Invertebrate Collection, Wellington, New Zealand. Abbreviations in the text are as follows:

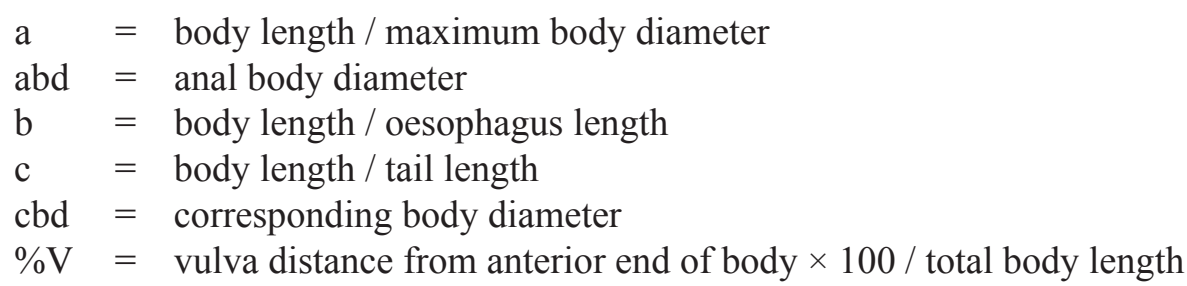




\title{
Results
}

\author{
Class Chromadorea Inglis, 1983 \\ Order Monhysterida Filipjev, 1929 \\ Superfamily Siphonolaimoidea Filipjev, 1918 \\ Family Linhomoeidae Filipjev, 1922
}

Diagnosis (From Fonseca \& Bezerra 2014)

Cuticle often striated, sometimes smooth. Inner labial sensillae papillose or not observable. Amphideal fovea usually circular, rarely unispiral. Inner side of labial region formed by an annular, soft-skinned pad that narrows the buccal opening. Cardia long and conspicuous. Usually two outstretched and opposed gonads, rarely single gonad present. Anterior gonad to the left or right of intestine, posterior gonad to the opposite side.

Subfamily Thelonematinae Bussau, 1993

\section{Type and only genus}

Thelonema Bussau, 1993.

\section{Diagnosis}

See diagnosis of type and only genus Thelonema.

Thelonema Bussau, 1993

Diagnosis (modified from Bussau 1993)

Inner labial sensillae not observable with light microscopy. Six outer labial setae situated in separate circle from the four sensillae of the third circle; the latter consists of papillae located in depressions. Four sub-cephalic setae located immediately posterior to the cephalic papillae. Large circular amphideal fovea located far posteriorly, and with nerve process usually visible. Buccal cavity cylindrical or funnelshaped, cuticularised, without teeth. Pharynx with weak posterior bulb; cardia long and gradually widening posteriorly. Female with two outstretched and opposed ovaries and male with two outstretched and opposed testes. Tail conico-cylindrical.

\section{Type species}

Thelonema majum Bussau, 1993.

Thelonema clarki sp. nov. urn:1sid:zoobank.org:act:F4ED998A-656F-48D1-8FBC-B0031BA943D9

Figs 1-3, Table 1

\section{Diagnosis}

Thelonema clarki sp. nov. is characterised by large adult body size $(3230-4461 \mu \mathrm{m})$, short cylindrical buccal cavity with cuticularised walls, sub-cephalic setae of similar length or shorter than outer labial setae, secretory-excretory system with two or three renette cells, gubernaculum without apophyses, and conico-cylindrical tail 6.4-10.4 abd long. 


\section{Etymology}

This species is named after Malcolm R. Clark, principal investigator of the HADES project (HADal Ecosystem Studies) who has made an outstanding contribution to the field of deep-sea ecology and who kindly supported the involvement of the author on the Kermadec Trench voyage.

\section{Material examined}

Holotype

KERMADEC TRENCH: ô (NIWA 99760), collected 6 May 2014 (WHOI cruise TN309, Nereus dive N074).

A

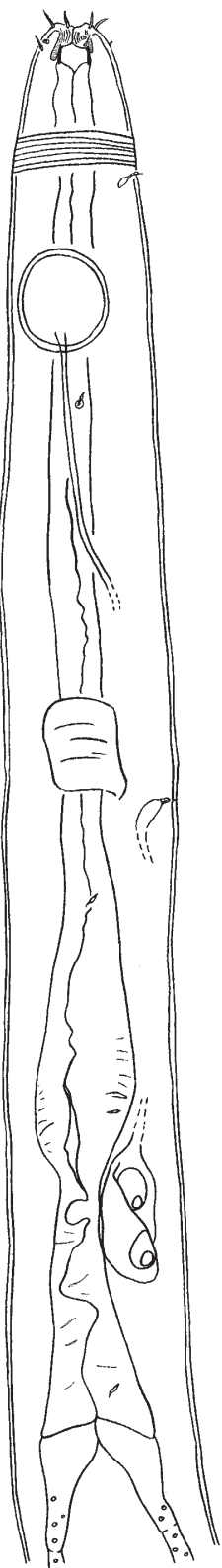

B

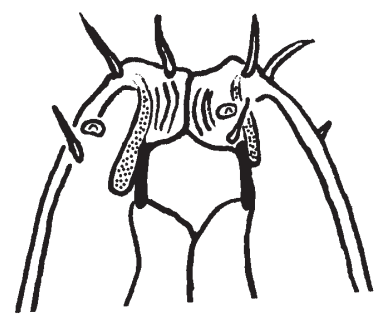

$E$

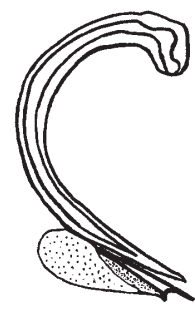

C

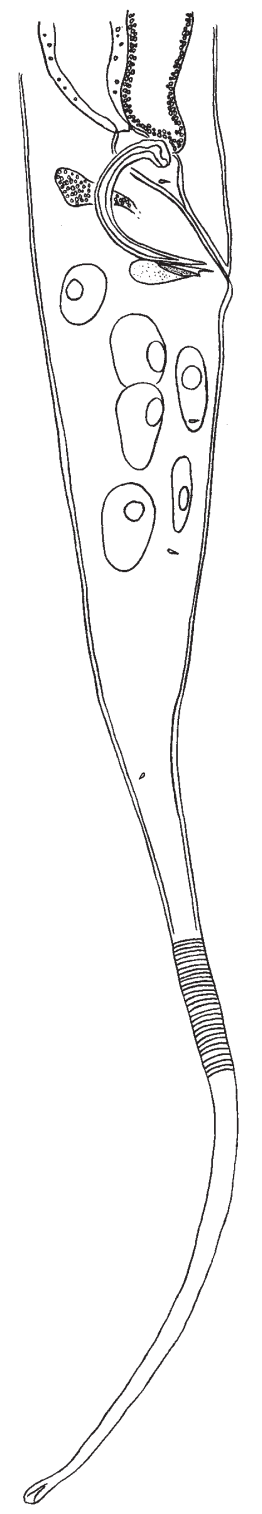

$\mathrm{D}$

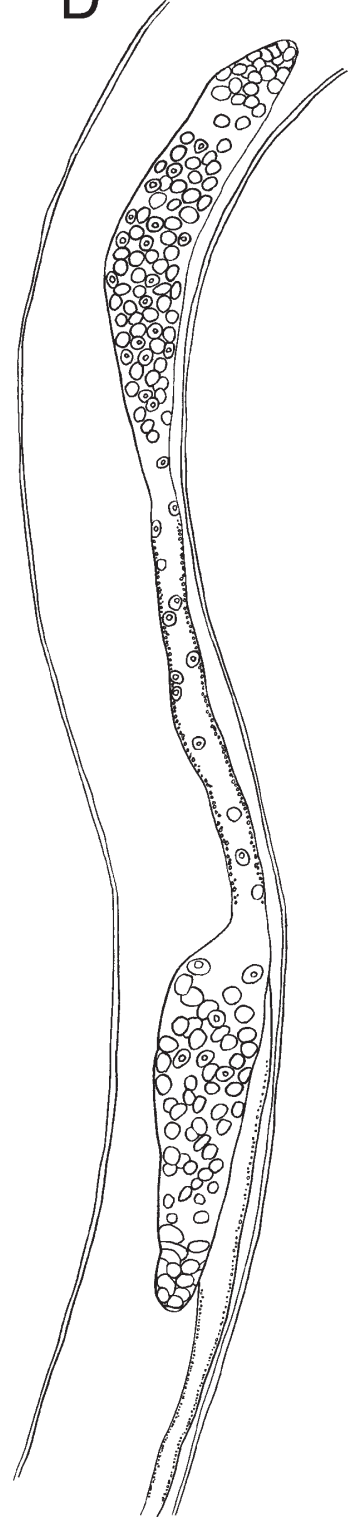

Fig. 1. Thelonema clarki sp. nov. Holotype, ठิ. A. Anterior body region. B. Head, showing buccal cavity and cephalic sensillae. C. Posterior body region. D. Gonads, right-hand side view. E. Spicule and gubernaculum. Scale bar: A, C $=40 \mu \mathrm{m} ; \mathrm{B}=12 \mu \mathrm{m} ; \mathrm{D}=45 \mu \mathrm{m} ; \mathrm{E}=20 \mu \mathrm{m}$. 


\section{Paratypes}

KERMADEC TRENCH: 2 q 9 (NIWA 99761) and 1 juvenile (NIWA 99762), collected 7 May 2014 (WHOI cruise TN309, Nereus dive N075).

\section{Type habitat}

KERMADEC TRENCH: water depth: $8081 \mathrm{~m}\left(178.17571^{\circ} \mathrm{W}, 34.34030^{\circ} \mathrm{S}\right)$, sediment depth: $2-3 \mathrm{~cm}$ (holotype); water depth: $9177 \mathrm{~m}\left(177.65414^{\circ} \mathrm{W}, 32.85037^{\circ} \mathrm{S}\right)$, sediment depth: 0-2 cm (paratype).
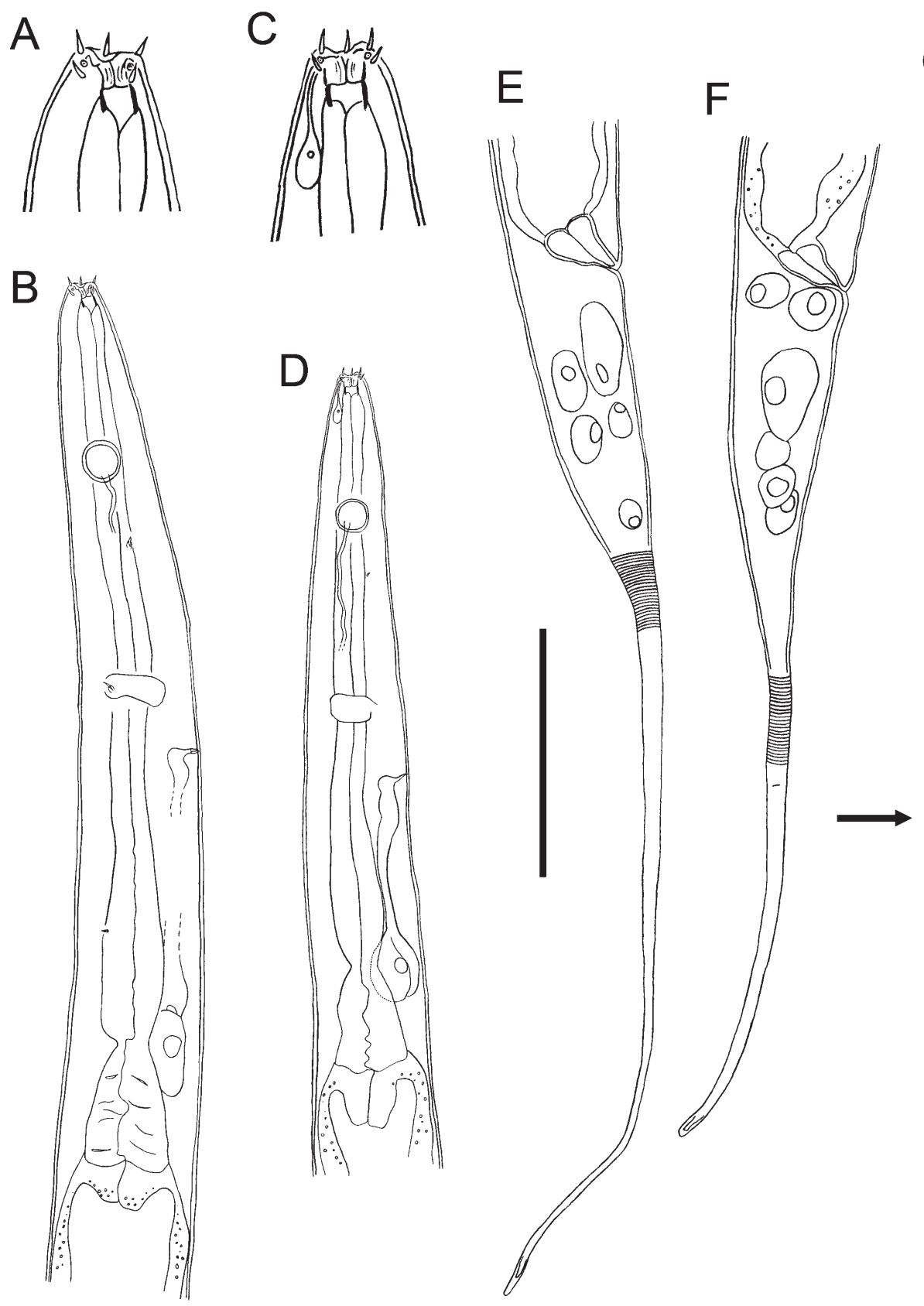

G
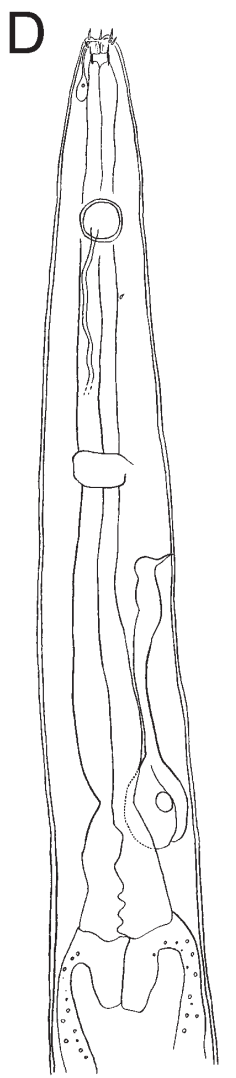

Fig. 2. Thelonema clarki sp. nov. Paratypes, $\circ$ and juvenile. A. Female head. B. Female anterior body region. C. Juvenile head. D. Juvenile anterior body region. E. Female posterior body region. F. Juvenile posterior body region. G. Female reproductive system. Arrow shows position of vulva. Scale bar: A-C $=40 \mu \mathrm{m} ; \mathrm{B}-\mathrm{D}=100 \mu \mathrm{m} ; \mathrm{E}-\mathrm{F}=90 \mu \mathrm{m} ; \mathrm{G}=210 \mu \mathrm{m}$. 


\section{Description}

Male

Body cylindrical, tapering slightly towards both extremities. Cuticle striated from level of buccal cavity to near tail tip. Somatic setae absent except for a few $1 \mu \mathrm{m}$ long setae in pharyngeal region. Lip region slightly concave; head region otherwise rounded. Internal labial sensillae not observed. Six outer labial setae, $5 \mu \mathrm{m}$ long, situated in separate circle from the four sensillae of third circle; the latter consists of papillae located in depressions (Fig. 3B). Small, granular glands sometimes observed, apparently connected to base of outer labial setae (Fig. 1B); larger unicellular glands also sometimes observed and apparently connected to cephalic sensillae (Fig. 2C). Four sub-cephalic setae located immediately posterior to the cephalic papillae, 3-4 $\mu \mathrm{m}$ long, similar in length or slightly shorter than outer labial setae. Large circular amphideal fovea with cuticularised outline situated $1.7 \mathrm{cbd}$ from anterior body extremity. Mouth opening narrow, surrounded by bulge of inner portion of lip region; buccal cavity cylindrical, $7 \mu \mathrm{m}$ deep, $9 \mu \mathrm{m}$ wide, with cuticularised walls, not surrounded by pharyngeal tissue. Pharynx narrow, muscular, with oval posterior bulb; pharyngeal glands and their orifices indistinct. Nerve ring slightly posterior to middle of pharynx length. Secretory-excretory system with two or three renette cells (third cell may sometimes be obscured) all situated just posterior to pharyngeal bulb; ampulla and pore between nerve ring and posterior pharyngeal bulb. Cardia conspicuous, $90 \mu \mathrm{m}$ long, widening posteriorly, not surrounded by intestine walls.

Reproductive system diorchic with two opposed and outstretched testes, anterior testis to the left of intestine and posterior testis to the right of intestine. Mature sperm globular, nucleated, 4-5 $\times$ 6-7 $\mu \mathrm{m}$. Spicules paired, 1.2 abd long, strongly arcuate, with well-developed capitulum and pointed distal end. Gubernaculum thin, pointed at both ends, without apophyses but with rounded glandular tissue extending dorsally. Rectal glands not observed; one ejaculatory gland situated between spicules. Pre-cloacal supplements absent. Tail long, conico-cylindrical, with rounded tip. Caudal glands not observed; short and sparse caudal setae present, no terminal setae. Intestine with numerous transparent crystalline structures, square to rhomboid-shaped, up to $14 \times 14 \mu \mathrm{m}$ (Fig. 3C-D).

\section{Female}

Similar to males but with lower values of a, b, and c, slightly smaller amphids (0.42-0.44 vs 0.65 cbd) and longer tail (9.0-10.4 vs 6.4 abd). Buccal cavity $5 \mu \mathrm{m}$ wide and 4-5 $\mu \mathrm{m}$ deep. Reproductive system didelphic; anterior branch outstretched, to the right of intestine, posteror branch poorly developed, to the left of intestine. Spermatheca present in anterior branch only, simple, not cuticularised. Vulva transverse, situated slightly posterior to mid-body; small vaginal glands present on either side of vagina; muscular pars proximalis vaginae.

\section{Juvenile}

Similar to females, but with shorter body and lower values of a and b.

\section{Remarks}

Thelonema clarki sp. nov. can be differentiated from the only other species of the genus, T. majum, by the larger body size (3230-4461 vs 1000-1460 $\mu \mathrm{m}$ ), short cylindrical buccal cavity (vs long and funnelshaped in T. majum), sub-cephalic setae of similar length or shorter than outer labial setae (sub-cephalic setae longer than outer labial setae in T. majum), secretory-excretory system with two or three renette cells (secretory-excretory system not observed in T. majum), absence of gubernacular apophyses (vs dorso-caudal apophyses present in T. majum), and longer tail (6.4-10.4 vs 2.7 abd).

This is the first time that Thelonema is recorded outside the type locality in the Peru Basin $(\sim 4150 \mathrm{~m}$ depth) since the original description of the genus by Bussau (1993). The genus was not included in 
LEDUC D., Kermadec Trench Monhysterida
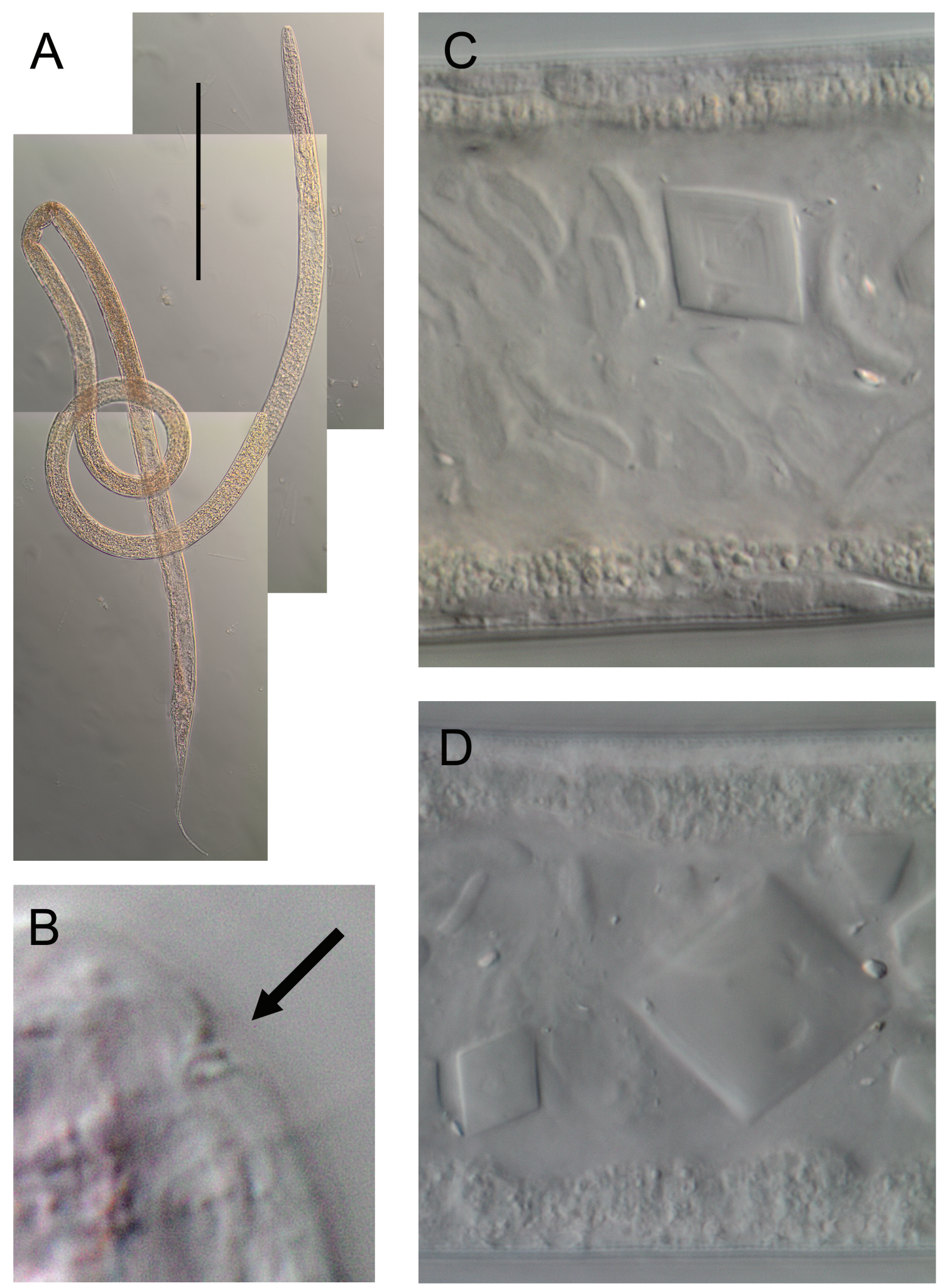

Fig. 3. Thelonema clarki sp. nov. Light micrographs. A. Holotype, ô, entire biody. B. Cross-section view of sunken papilla, second circle of cephalic sensillae. C. Female gut content, showing crystalline structures and other unidentified contents. D. Juvenile gut showing crystalline structures. Arrow shows position of sunken papilla of third circle of cephalic sensillae. Scale bar: A $=520 \mu \mathrm{m} ; \mathrm{B}=5 \mu \mathrm{m} ; \mathrm{C}-\mathrm{D}=$ $20 \mu \mathrm{m}$. 
Table 1. Morphometrics $(\mu \mathrm{m})$ of Thelonema clarki sp. nov., Metasphaerolaimus constrictus sp. nov., and Monhystrella kermadecensis sp. nov. (n, number of specimens; L, body length; V, vulva distance from anterior end of body).

\begin{tabular}{|c|c|c|c|c|c|c|c|c|}
\hline \multirow[t]{3}{*}{ Species } & \multicolumn{3}{|c|}{ Thelonema clarki sp. nov. } & \multicolumn{2}{|c|}{$\begin{array}{l}\text { Metasphaerolaimus constrictus } \\
\text { sp. nov. }\end{array}$} & \multicolumn{3}{|c|}{ Monhystrella kermadecensis sp. nov. } \\
\hline & \multirow{2}{*}{$\begin{array}{c}\text { Male } \\
\text { Holotype }\end{array}$} & \multirow{2}{*}{$\begin{array}{c}\text { Females } \\
\text { Paratypes }\end{array}$} & \multirow{2}{*}{$\begin{array}{l}\text { Juvenile } \\
\text { Paratype }\end{array}$} & \multirow{2}{*}{$\begin{array}{c}\text { Male } \\
\text { Holotype }\end{array}$} & \multirow{2}{*}{$\begin{array}{c}\text { Females } \\
\text { Paratypes }\end{array}$} & \multicolumn{2}{|c|}{ Males } & \multirow{2}{*}{$\begin{array}{c}\text { Females } \\
\text { Paratypes }\end{array}$} \\
\hline & & & & & & Holotype & Paratypes & \\
\hline $\mathrm{n}$ & - & 2 & 1 & - & 3 & - & 2 & 5 \\
\hline $\mathrm{L}$ & 4461 & 3230,3251 & 2217 & 1232 & $1604-1623$ & 497 & 473,492 & $429-480$ \\
\hline $\mathrm{a}$ & 81 & 49,52 & 38 & 33 & $30-33$ & 36 & 36,41 & $32-35$ \\
\hline $\mathrm{b}$ & 14 & 11 & 9 & 5 & 6 & 5 & 5 & 5 \\
\hline $\mathrm{c}$ & 13 & 8,9 & 9 & 13 & $12-14$ & 7 & 6,7 & 7 \\
\hline Head diam. at ceph. setae & 21 & 13,15 & 12 & 20 & $21-26$ & 4 & 4 & $3-4$ \\
\hline Head diam. at amphid & 40 & 34,36 & 29 & 31 & $36-37$ & 7 & 6,7 & $6-7$ \\
\hline Length of sub-cephalic setae & 4 & 3 & 3 & $3-7$ & $4-9$ & $1-2$ & $1-2$ & $1-2$ \\
\hline Length of cephalic setae & - & - & - & $2-3$ & $2-3$ & 1 & 1 & 1 \\
\hline Amphid height & 29 & 16 & 14 & 15 & 5 & 3 & 3 & 3 \\
\hline Amphid width & 26 & 15 & 14 & 15 & $4-5$ & 3 & 3 & $2-3$ \\
\hline Amphid width/cbd (\%) & 65 & 42,44 & 48 & 48 & $11-14$ & 43 & 43,50 & $33-43$ \\
\hline Amphid from anterior end & 66 & 64,65 & 51 & 42 & $38-49$ & 13 & 12,13 & $12-14$ \\
\hline Nerve ring from anterior end & 156 & 152,156 & 119 & 117 & $126-135$ & 55 & 55 & $51-58$ \\
\hline Nerve ring cbd & 48 & 47,49 & 39 & 37 & $46-47$ & 11 & 10 & $10-11$ \\
\hline Excretory pore from anterior end & 221 & 188,191 & 167 & - & - & - & - & - \\
\hline Pharynx length & 323 & 289,290 & 238 & 234 & $271-283$ & 93 & 88,97 & $87-95$ \\
\hline Pharynx diameter at base & 28 & 23,25 & 23 & 25 & $32-37$ & 7 & 7,8 & $6-7$ \\
\hline Pharynx cbd at base & 51 & 53,57 & 49 & 36 & $47-49$ & 12 & 12,13 & $11-12$ \\
\hline Max. body diam. & 55 & 63,66 & 58 & 37 & $49-54$ & 14 & 12,13 & $12-14$ \\
\hline Spicule length & 62 & - & - & 40 & - & 20 & 19,21 & - \\
\hline Gubernaculum length & 16 & - & - & - & - & 5 & 5 & - \\
\hline Anal body diam. & 53 & 40,41 & 39 & 31 & $41-46$ & 12 & 12 & $6-9$ \\
\hline Tail length & 338 & 361,427 & 285 & 94 & $118-132$ & 74 & 70,80 & $66-78$ \\
\hline Tail length/abd & 6.4 & $9.0,10.4$ & 7.3 & 3.0 & $2.9-3.1$ & 6.2 & $5.8,6.7$ & $7.8-11.0$ \\
\hline $\mathrm{V}$ & - & 1785,1835 & - & - & $995-1025$ & - & - & $272-308$ \\
\hline$\% \mathrm{~V}$ & - & 55,57 & - & - & $62-64$ & - & - & $62-64$ \\
\hline Vulval body diam. & - & 63,65 & - & - & $49-54$ & - & - & $11-13$ \\
\hline
\end{tabular}


the recent overview of all Monhysterida by Fonseca \& Bezerra (2014), but the discovery of a new Thelonema species in the Southwest Pacific confirms the validity of the genus.

The presence of crystalline structures in the intestine is intriguing, as many appear too large to have been ingested (the structures are up to $14 \mu \mathrm{m}$ wide, and the width of the cuticularised buccal cavity is 4-9 $\mu \mathrm{m}$ ). It seems unlikely that the buccal cavity can stretch to accommodate such large particles given the presence of cuticularised walls. The crystalline structures may have grown through accretion whilst in the intestine, but this process would presumably require a relatively long period of time.

Superfamily Sphaerolaimoidea Filipjev, 1918

Family Sphaerolaimidae Filipjev, 1918

Diagnosis (from Fonseca \& Bezerra 2014)

Cuticle striated or annulated. Six outer labial setae and four cephalic setae in one circle, with cephalic setae longer than outer labial setae. Eight groups of sub-cephalic setae present (four groups in Megalamphis). Buccal cavity wide, barrel-shaped (except for Subsphaerolaimus Lorenzen, 1978, which is conical), with longitudinal ribs, surrounded only at the base by pharyngeal tissue. Pharyngeal lumen with thick cuticle. Renette cell usually present, opening behind nerve ring. Females with one outstretched anterior ovary at left or right of intestine. Males usually with two testes; anterior one either to the left or right of intestine, posterior one at opposite side.

Subfamily Metasphaerolaiminae Gourbault \& Boucher, 1981

\section{Type genus}

Metasphaerolaimus Gourbault \& Boucher, 1981.

\section{Diagnosis}

See diagnosis of type and only genus Metasphaerolaimus.

Genus Metasphaerolaimus Gourbault \& Boucher, 1981

Ceratosphaerolaimus Fadeeva, 1983: 1329, fig. 5. (see Jensen 1992: 8)

Diagnosis (modified from Fonseca \& Bezerra 2014)

Cuticle finely striated. Six inner labial papillae; six outer labial setae at same level as four longer cephalic setae; eight groups of sub-cephalic setae. Amphideal fovea circular, situated posteriorly to buccal cavity. Buccal cavity strongly cuticularised with six H- or X-shaped mandibles, hooked anteriorly and articulating on cuticularised rim posteriorly. Pharynx cylindrical with strongly cuticularised lumen.

\section{Type species}

M. cancellatus Gourbault \& Boucher, 1981.

Metasphaerolaimus constrictus sp. nov. urn:1sid:zoobank.org:act:C2DD1CB2-2B9B-4C31-BF13-C0E1A143A275

Figs 4-5, Table 1

\section{Diagnosis}

Metasphaerolaimus constrictus sp. nov. is characterised by a relatively long body (1232-1623 $\mu \mathrm{m})$, amphids located 1.0-1.4 cbd from anterior extremity, slightly arcuate spicules 1.3 abd long without 
A

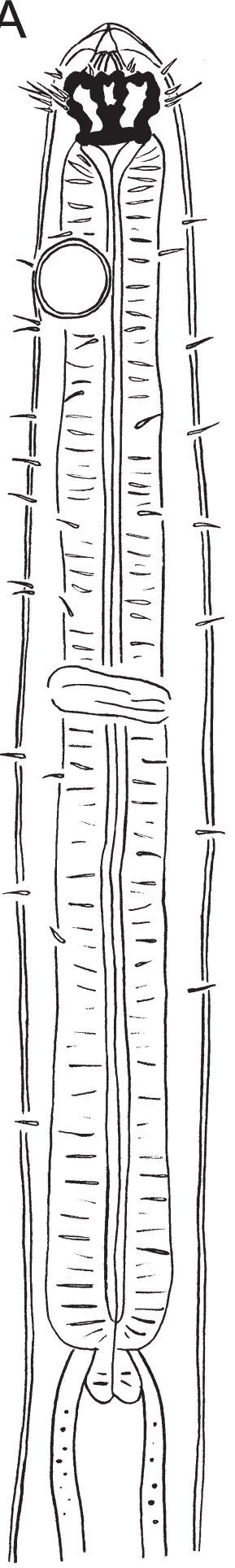

B

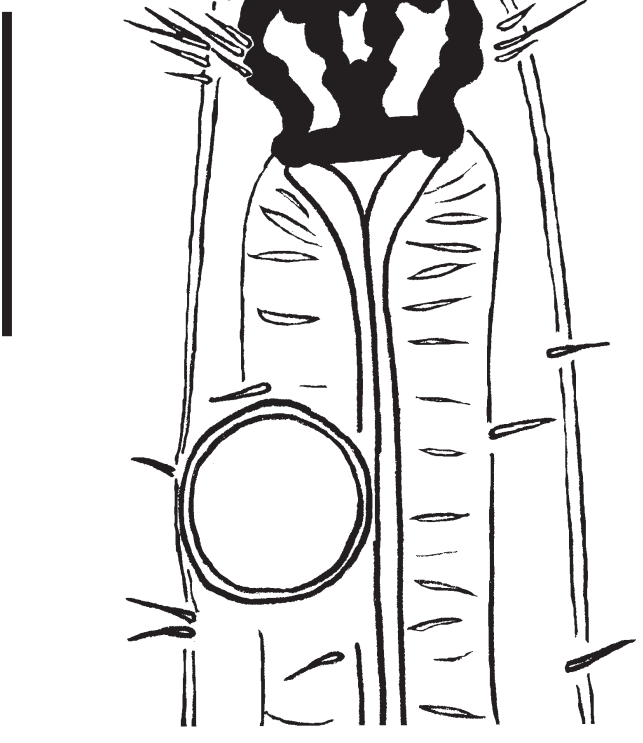

C

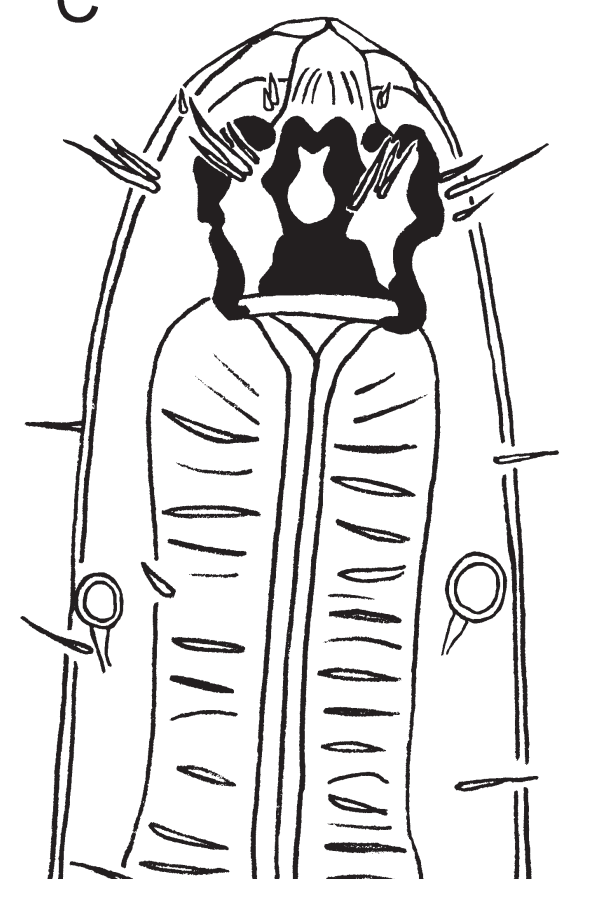

D

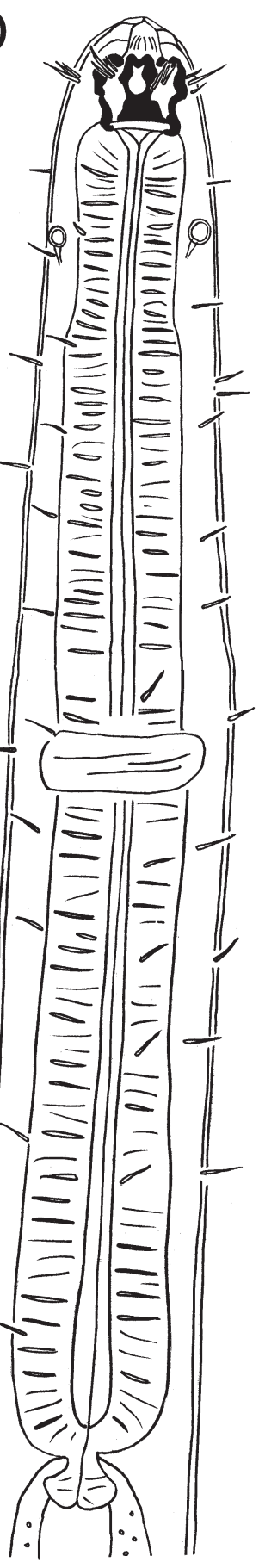

Fig. 4. Metasphaerolaimus constrictus sp. nov. A. Holotype, $\widehat{\partial}$, anterior body region. B. Holotype, $\hat{\partial}$, head. C. Female head. D. Female anterior body region. Scale bar: A $=50 \mu \mathrm{m} ; \mathrm{B}-\mathrm{C}=25 \mu \mathrm{m} ; \mathrm{D}=55 \mu \mathrm{m}$. 
gubernaculum, tail conico-cylindrical with inner cuticle conspicuously thickened immediately anterior to cylindrical portion and with three short terminal setae.

\section{Etymology}

The species name is derived from the latin constrictus (= drawn together or contracted), and refers to the distinctive shape of the tail with thickening of the inner cuticle.

\section{Material examined}

Holotype

KERMADEC TRENCH: ${ }^{\lambda}$ (NIWA 99763), collected 6 May 2014 (WHOI cruise TN309, Nereus dive N074).

Paratypes

KERMADEC TRENCH: 3 우 (NIWA 99764-6), collected 7 May 2014 (WHOI cruise TN309, Nereus dive N075).

\section{Type habitat}

KERMADEC TRENCH: water depth: $8081 \mathrm{~m}\left(178.17571^{\circ} \mathrm{W}, 34.34030^{\circ} \mathrm{S}\right)$, sediment depth: $2-3 \mathrm{~cm}$ (holotype); water depth: $9177 \mathrm{~m}\left(177.65414^{\circ} \mathrm{W}, 32.85037^{\circ} \mathrm{S}\right)$, sediment depth: 0-2 cm (paratype).

\section{Description}

\section{Male}

Body cylindrical, tapering slightly towards both extremities. Cuticle faintly striated along entire body. Eight rows of somatic setae, relatively long $(4-7 \mu \mathrm{m})$ and numerous in pharyngeal region, short and sparse elsewhere. Head rounded, with well-developed lip region. Inner labial sensillae not observed; six outer labial setae, 1-2 $\mu \mathrm{m}$ long, and four cephalic setae, 2-3 $\mu \mathrm{m}$ long, in one circle. Eight groups of three to four sub-cephalic setae, 3-8 $\mu \mathrm{m}$ long. Large circular amphideal fovea with strongly cuticularised outline, $1.4 \mathrm{cbd}$ from anterior body extremity. Buccal cavity large, $24 \mu \mathrm{m}$ deep and $13 \mu \mathrm{m}$ wide; six $\mathrm{H}$-shaped mandibles hooked anteriorly and with wide base articulating onto cuticularised rim posteriorly. Posterior portion of buccal cavity surrounded by pharyngeal tissue. Pharynx muscular, cylindrical, widening very slightly towards posterior extremity, with strongly cuticularised lumen. Cardia extend into intestine lumen. Nerve ring situated at middle of pharynx length. Secretory-excretory system not observed.

Reproductive system diorchic with two outstretched testes; anterior testis to the left and posterior testis to the right of intestine. Mature sperm cells nucleated, spherical to globular, $9 \times 9-13 \mu \mathrm{m}$. Spicules 1.3 abd long, slightly arcuate, with swollen proximal ends and pointed distal ends. Gubernaculum and pre-cloacal supplements absent. Tail conico-cylindrical with conspicuous thickening of inner cuticle (maximum thickness $\sim 7 \mu \mathrm{m}$ ) immediately anterior to cylindrical portion (Fig. 5D); cylindrical portion shorter than conical portion. A few short, sparse caudal setae present sub-ventrally and sub-dorsally; three short terminal setae, $2 \mu \mathrm{m}$ long. Caudal glands not observed.

\section{Female}

Similar to male, but with longer body and substantially smaller amphids (0.11-0.14 vs 0.48 cbd) situated 1.0-1.4 cbd from anterior body extremity. Reproductive system monodelphic with outstretched anterior branch to the left or right of intestine. Spermatheca present, simple and not cuticularised. Vulva transverse, situated at almost two thirds of body length from anterior. Vaginal glands not observed. Three caudal glands observed in one specimen. Cuticle immediately anterior to cylindrical portion of tail up to $9 \mu \mathrm{m}$ thick. 


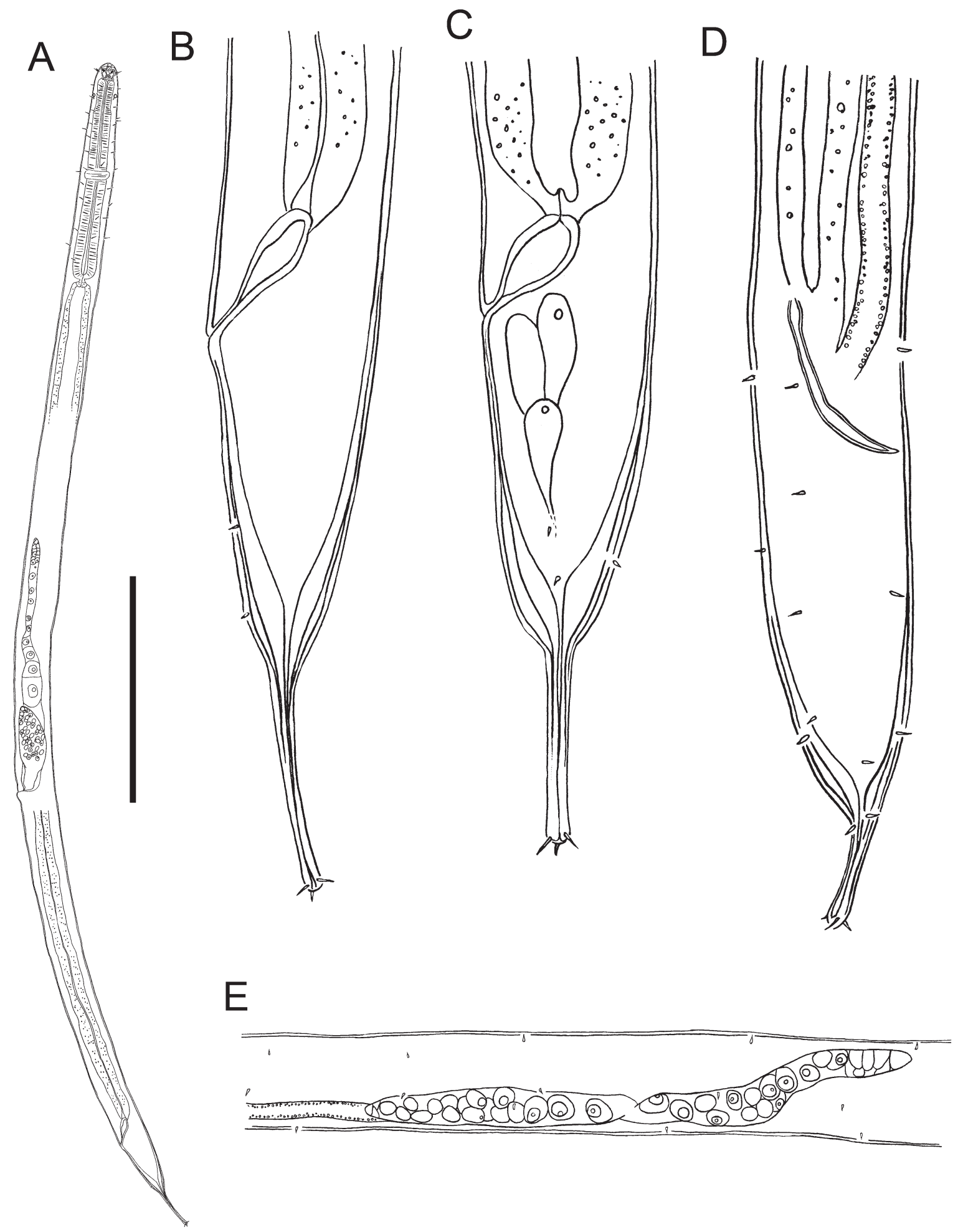

Fig. 5. Metasphaerolaimus constrictus sp. nov. A. Entire ${ }_{+}$. B-C. Female posterior body region. D. Male posterior body region. E. Male gonads. Scale bar: $A=300 \mu \mathrm{m} ; \mathrm{B}-\mathrm{C}=55 \mu \mathrm{m} ; \mathrm{D}=45 \mathrm{~mm} ; \mathrm{E}=80 \mu \mathrm{m}$. 
LEDUC D., Kermadec Trench Monhysterida

\section{Remarks}

Metasphaerolaimus constrictus sp. nov. can be differentiated from all other species of the genus by the distinctive tail shape with conspicuous thickening of cuticle (up to 7-9 $\mu \mathrm{m}$ thick) immediately anterior to the cylindrical portion. M. constrictus sp. nov. is most similar to M. gerlachi Jensen, 1992, M. hadalis (Freudenhammer, 1975), and M. inglisi Gourbault \& Boucher, 1981. The new species can be differentiated from M. gerlachi based on larger body size (1232-1623 vs 893-971 $\mu \mathrm{m})$, larger amphids in males ( 0.48 vs $0.30-0.40 \mathrm{cbd}$ ), and presence of short terminal setae (vs long terminal setae in $M$. gerlachi); from $M$. hadalis by higher values of a (30-38 vs 26-27), larger amphids in males (0.48 vs $0.35 \mathrm{cbd}$ ) and shorter tail (2.9-3.1 vs 3.4-3.8 abd); from M. inglisi by the absence of setae immediately anterior to amphids in females (vs three long setae in M. inglisi), and presence of terminal setae (absent in M. inglisi).

Metasphaerolaimus was initially described by Gourbault \& Boucher (1981) to accommodate species similar to Sphaerolaimus Bastian, 1865, but with a buccal cavity with six mandibles instead of a solid, heavily cuticularised capsule. Gourbault \& Boucher (1981) described three new species (Metasphaerolaimus cancellatus Gourbault \& Boucher, 1981, M. hamatus Gourbault \& Boucher, 1981 and M. inglisi Gourbault \& Boucher, 1981), and transferred the species Sphaerolaimus campbelli Allgén, 1927, Sphaerolaimus hadalis Freudenhammer, 1975, and Sphaerolaimus crassicauda Freudenhammer, 1975 to Metasphaerolaimus. Fadeeva (1983) later described the identical genus Ceratosphaerolaimus Fadeeva, 1893, including one new species (Ceratosphaerolaimus japonicus Fadeeva, 1983); the latter author also transferred Sphaerolaimus horrendus Sergeeva, 1981 to Ceratosphaerolaimus. Ceratosphaerolaimus was synonymised with Metasphaerolaimus by Jensen (1992), who also described Metasphaerolaimus gerlachi Jensen, 1992. There are currently ten valid Metasphaerolaimus species including Metasphaerolaimus constrictus sp. nov. (Table 2). Species of this genus are mainly differentiated based on amphideal fovea size, spicule length, and length and shape of the tail. The majority of species occur in the deep sea below $1000 \mathrm{~m}$ depth, except for Metasphaerolaimus campbelli, M. horrendus, and M. japonicus, which were described from coastal waters. These three shallow water species are also the only species of the genus that possess a gubernaculum with dorso-caudal apophyses.

Superfamily Monhysteroidea Filipjev, 1929

Family Monhysteridae de Man, 1876

Diagnosis (modified from Fonseca \& Decraemer 2008)

Small, slender nematodes usually less than $2.5 \mathrm{~mm}$ long. Cuticle smooth or striated. Anterior sensillae in two circles: anterior circle with six inner labial sensillae (usually papilliform) and posterior circle with six outer labial sensillae and four cephalic sensillae (both usually setiform). Amphideal fovea circular or cryptocircular. Buccal cavity small to medium-sized, bipartite or single, with or without denticles. Pharynx with or without posterior bulb. Secretory-excretory system present or absent. Female reproductive system monodelphic with outstretched gonad to the right of intestine; male monorchic with anterior testis to the right of intestine (except Monhystrella kermadecensis sp. nov. where position of anterior gonad relative to intestine is variable). Spicules usually simple and arcuate. Tail conical to conico-cylindrical; terminal setae absent.

\section{Genus Monhystrella Cobb, 1918}

Diagnosis (modified from Fonseca \& Decraemer 2008)

Short body length $(<0.8 \mathrm{~mm})$. Small somatic setae often present. Six outer labial and four cephalic sensillae usually setiform. Buccal cavity tubiform, funnel-shaped or conoid, often with cuticularised walls; denticles usually present, but difficult to observe in small species. Circular amphideal fovea 
Table 2. Key morphological characteristics of all valid Metasphaerolaimus species, and their bathymetric distribution. A: dorso-caudal apophyses present; $\mathrm{Co}=$ conical; $\mathrm{CoC}=$ conico-cylindrical; $\mathrm{G}=$ gurbernaculum present; $\mathrm{nd}=$ no data; - = absent. Depth range data based on type locality and additional distribution data summarised by Jensen (1992).

\begin{tabular}{|c|c|c|c|c|c|c|c|c|c|c|c|}
\hline & $\mathbf{L}$ & a & b & c & $\begin{array}{c}\text { Amphid width \% } \\
\text { cbd } \\
\text { (male, female) }\end{array}$ & $\begin{array}{l}\text { Spicule } \\
\text { length }\end{array}$ & $\begin{array}{l}\text { Gubenaculum?/ } \\
\text { Dorso-caudal } \\
\text { apophyses? }\end{array}$ & $\% \mathbf{V}$ & $\begin{array}{c}\text { Tail } \\
\text { shape }\end{array}$ & $\begin{array}{c}\text { Tail } \\
\text { length } \\
\text { abd }\end{array}$ & $\begin{array}{c}\text { Depth } \\
\text { range (m) }\end{array}$ \\
\hline M. campbelli (Allgén, 1927) & 830 & 24 & 4 & 7 & 37 , nd & 41 & $\mathrm{G} / \mathrm{A}$ & nd & $\mathrm{CoC}$ & 4.6 & $<20$ \\
\hline M. cancellatus Gourbault \& Boucher, 1981 & $730-1050$ & $26-35$ & $4-5$ & $8-10$ & $50-58,22$ & 30 & G/- & 61 & $\mathrm{CoC}$ & $3.6-5.0$ & 4308 \\
\hline M. constrictus sp. nov. & $1232-1623$ & $30-38$ & $5-6$ & $12-14$ & $48,11-14$ & 40 & $-/-$ & $62-64$ & $\mathrm{CoC}$ & $2.9-3.1$ & $8081-9177$ \\
\hline M. crassicauda (Freudenhammer, 1975) & $650-810$ & $25-34$ & $4-5$ & $10-16$ & $47-50,12-15$ & $20-26$ & $-/-$ & $63-69$ & $\mathrm{Co}$ & $2.3-3.0$ & $970-4725$ \\
\hline M. gerlachi Jensen, 1992 & $893-971$ & $28-32$ & 4 & $8-9$ & $32-40$, nd & 30 & $-/-$ & nd & $\mathrm{CoC}$ & 3.3 & $1245-1426$ \\
\hline M. hadalis (Freudenhammer, 1975) & $1230-1440$ & $26-27$ & $4-5$ & $10-11$ & 35,14 & 46 & $-/-$ & 65 & $\mathrm{CoC}$ & $3.4-3.8$ & $1920-6313$ \\
\hline M. hamatus Gourbault \&z Boucher, 1981 & $885-951$ & $25-31$ & $4-5$ & $10-11$ & $50,20-21$ & 30 & $\mathrm{G} /-* *$ & $58-59$ & Co & $2.9-3.1$ & $1286-2944$ \\
\hline M. horrendus (Sergeeva, 1981) & $663-998$ & $16-27$ & $4-6$ & $8-11$ & $21-25,12-15$ & $23-29$ & $\mathrm{G} / \mathrm{A}$ & $59-63$ & Co & $2.6-3.2$ & $60-110$ \\
\hline M. inglisi Gourbault \& Boucher, 1981 & $1100-1350$ & $23-24$ & 4 & 9 & nd, $17-20$ & nd & nd & $70-74$ & $\mathrm{CoC}$ & $3.4-3.6$ & 2063-2944 \\
\hline M. japonicus (Fadeeva, 1983) & $1120-2100$ & $16-26$ & $3-5$ & $6-9$ & 35,15 & $63-78$ & $\mathrm{G} / \mathrm{A}^{*}$ & $50-77$ & $\mathrm{CoC}$ & $4.0-5.0$ & $16-32$ \\
\hline
\end{tabular}

*Dorso-caudal apophyses present but very thin and may be difficult to observe.

**From re-description by Jensen (1992) 
usually $1.5-2.0$ or more head diameters from anterior end. Posterior part of pharynx enlarged forming a single or double bulb without valves. Secretory-excretory system usually absent. Female reproductive system short to medium sized; vulva near mid-body. Spicules mostly arcuate and short $(<2$ abd). Tail usually with ventrally curved conical anterior portion and dorsally curved cylindrical filiform posterior portion. Spinneret a long and slender cone or cylinder.

\section{Remarks}

The taxonomy of all marine Monhystrella species was revised by Fonseca \& Decraemer (2008), who provided a detailed diagnosis of the genus and a key to all thirteen valid marine species; no new marine species have been described since.

\section{Monhystrella kermadecensis sp. nov. urn:Isid:zoobank.org:act:AA638C6A-E7A8-4636-A03D-8CF851B70498}

Fig. 6, Table 1

\section{Diagnosis}

Monhystrella kermadecensis sp. nov. is characterised by circle of papillose outer labial sensillae slightly anterior to circle of four short cephalic setae, amphideal fovea $1.9 \mathrm{cbd}$ from anterior extremity and 0.33 $0.43 \mathrm{cbd}$ (females) or $0.43-0.50 \mathrm{cbd}$ (males), gubernaculum with caudal apophyses, presence of distinct cuticularised piece along anterior vaginal wall, relatively short conical (males) or conico-cylindrical tail (females) with conical, ventrally-curved spinneret.

\section{Etymology}

This species is named after the type locality.

\section{Material examined}

Holotype

KERMADEC TRENCH: $\widehat{\jmath}$ (NIWA 99767), collected 6 May 2014 (WHOI cruise TN309, Nereus dive N074).

\section{Paratypes}

KERMADEC TRENCH: 2 $\widehat{\partial}$ (NIWA 99768) and 5 우 (NIWA 99769) same data as holotype.

\section{Type habitat}

KERMADEC TRENCH: water depth: $8081 \mathrm{~m}\left(178.17571^{\circ} \mathrm{W}, 34.34030^{\circ} \mathrm{S}\right)$, sediment depth: $0-1 \mathrm{~cm}$.

\section{Description}

\section{Male}

Body cylindrical, tapering slightly towards both extremities. Cuticle smooth. Anterior end rounded or slightly truncated. Six minute inner labial papillae, difficult to observe; circle of six small outer labial papillae slightly anterior to circle of four short cephalic setae, $0.23 \mathrm{cbd}$ long. Amphideal fovea mediumsized, circular, situated $1.9 \mathrm{cbd}$ from anterior end, outline not cuticularised. Two short setae situated in sublateral row posterior to amphideal fovea. Buccal cavity small, funnel-shaped, surrounded by pharyngeal tissue. Pharynx gradually widening posteriorly, apparently forming a weak posterior bulb in some cases. Nerve ring situated slightly posterior to middle of pharynx. Secretory-excretory system not observed. Cardia small, partly surrounded by intestinal tissue. Progaster not observed. Distinct layer of glycocalyx present in intestinal lumen. 


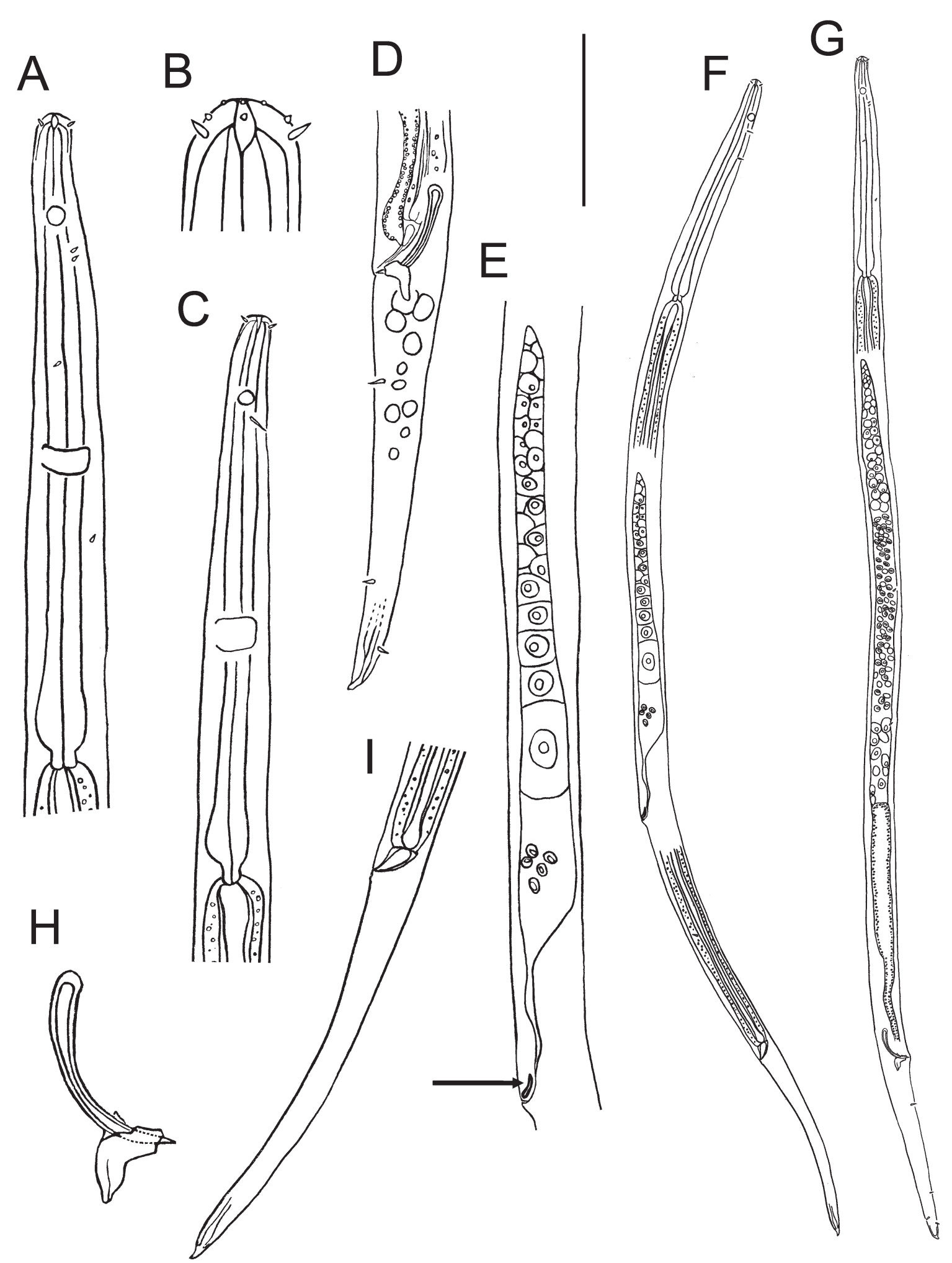

Fig. 6. Monhystrella kermadecensis sp. nov. A. Male anterior body region. B. Male head region. C. Female anterior body region. D. Male posterior body region. E. Female reproductive system. F. Entire . G. Entire $\widehat{\delta}$, holotype. H. Male copulatory apparatus. I. Female posterior body region. Arrow shows position of cuticularised piece anterior to vulva. Scale bar: A, C-E, I $=25 \mu \mathrm{m} ; \mathrm{B}=7 \mu \mathrm{m} ; \mathrm{F}-\mathrm{G}=70 \mu \mathrm{m}$; $\mathrm{H}=12 \mu \mathrm{m}$. 
Reproductive system monorchic with anterior outstretched testis situated to left or right of intestine. Mature sperm nucleated, globular, 1.3-2.0 × 1.5-2.4 $\mu \mathrm{m}$. Spicules paired, arcuate, without capitulum, widest at proximal end and with pointed distal tip. Gubernaculum with caudal apophyses and wide lateral crurae. Pre-cloacal supplements or setae not observed. Tail conical, with two pairs of sub-ventral setae and one pair of sub-dorsal setae. Well-developed, ventrally curved, conical spinneret; caudal glands not observed.

\section{Female}

Similar to males but body widest immediately anterior to vulva, then markedly smaller immediately posterior to vulva; body width decreases gradually towards both extremities. Amphideal fovea slightly smaller than in males $(0.33-0.43$ vs $0.43-0.50 \mathrm{cbd})$, only one seta present posterior to amphideal fovea; tail longer than in males (7.8-11.0 vs 6.2-6.7 abd), conico-cylindrical, without setae. Reproductive system monodelphic with outstretched anterior branch to the left (two specimens) or right of intestine (three specimens). Mature egg dimensions up to $12 \times 39 \mu \mathrm{m}$. Vulva located at almost two thirds of body length from anterior. Vagina transverse or oblique, with distinct cuticularised piece situated along anterior wall (Fig. 6D). No vaginal glands visible. Post-vulvar sac not observed.

\section{Remarks}

Monhystrella kermadecensis sp. nov. differs from most other Monhystrella species (except M. marina Timm, 1964) by the relatively short tail lacking a cylindrical filiform posterior portion. This trait may suggest affinities with Thalassomonhystera Jacobs, 1987, but species of this genus always possess a well-developed secretory-excretory system and lack a posterior pharyngeal bulb (Fonseca \& Decraemer 2008). M. kermadecensis sp. nov. is also unusual in the position of the vulva at almost two thirds of body length from the anterior extremity instead of near mid-body, a trait which suggests affinities with Halomonhystera Andrássy, 2006. The vulva in M. kermadecensis sp. nov. is, however, situated more anteriorly than in Halomonhystera (62-64 vs 76-92\% of body length from anterior extremity); the new species also differs from Halomonhystera in the absence of secretory-excretory system and shape of the buccal cavity (Fonseca \& Decraemer 2008). Elucidating the taxonomic relationships between M. kermadecensis sp. nov. and other Monhysteridae will require detailed molecular analyses which are not possible at present based on available specimens.

The holophyly of the Monhysteridae was established based on the anterior gonad always positioned to the right of the intestine (Lorenzen 1981). Monhystrella kermadecensis sp. nov. can be differentiated from all other species of the genus, and indeed the entire family, based on the variable position of the anterior gonad relative to the intestine (to the right or left of intestine in both sexes). The holophyly of the closely related family Xyalidae was established based on the anterior gonad always positioned to the left of the intestine and the posterior gonad (when present) always to the right of it (Lorenzen 1981). The new species therefore shows affinities with both the Mohysteridae and Xyalidae; within the Xyalidae it resembles the genus Theristus Bastian, 1965 most due to the conical shape of the tail and lack of terminal setae. The following traits, however, suggest closer affinities with the Monhysteridae: small body size $(<500 \mu \mathrm{m}$ in length), smooth cuticle (always striated in Xyalidae; Lorenzen 1981), presence of only four setae in second circle (always ten setae in Theristus), and presence of only one testis (two testes often present in Xyalidae).

\section{Discussion}

Monhystrella kermadecensis sp. nov. was among the most common species at the $8081 \mathrm{~m}$ site in Kermadec Trench and represented $8 \%$ of total nematode abundance (D. Leduc unpublished data). This species, however, was not present at the $9177 \mathrm{~m}$ site. Thelonema clarki sp. nov. and Metasphaerolaimus constrictus sp. nov. were relatively common at the $9177 \mathrm{~m}$ site, representing 3 and 5\%, respectively, of 
total nematode abundance. These two species were also present at the $8081 \mathrm{~m}$ site but in lower numbers ( $\leq 1 \%$ of total nematode abundance). The present study increases the number of nematode species known from hadal trench environments from fifteen to eighteen. Many more species are yet to be discovered and described, and future sampling in trench environments should ensure that preservation and fixation methods allow for both morphological and molecular analyses to be conducted (Yoder et al. 2006).

\section{Acknowledgments}

Funding was provided by NIWA's Coasts and Oceans Centre Research Programme 2 (2013/14 SCI) and the programme "Impact of resource use on vulnerable deep-sea communities" (CO1X0906). I am grateful to Tim Shank, principal investigator of the HADES project (HADal Ecosystem Studies, funded by the National Science Foundation (NSF-OCE1130712, 1130494 and 1131620), and to expedition leader Casey Machado, the officers, crew and scientific staff of $R V$ Thomas G. Thompson (voyage TN309), and ROV Nereus engineers and technicians. I thank three anonymous reviewers for providing constructive criticisms on the manuscript.

\section{References}

Bussau C. 1993. Taxonomische und ökologische Untersuchungen an Nematoden des Peru-Beckens. $\mathrm{PhD}$ thesis, University of Kiel, Germany.

Fadeeva N.P. 1983. A contribution to the family Sphaerolaimidae Filipjev, 1918 (Nematoda, Monhysterida) from the Sea of Japan. Zoologichesky Zhurnal 9: 1321-1333.

Fonseca G. \& Decraemer W. 2008. State of the art of the free-living marine Monhysteridae. Journal of the Marine Biological Association of the United Kingdom 88: 1371-1390. http://dx.doi.org/10.1017/ $\underline{\mathrm{S} 0025315408001719}$

Fonseca G. \& Bezerra T.N. 2014. Order Monhysterida. In: Schmidt-Rhaesa A. (ed.) Handbook of Zoology Gastrotricha, Cyclioneura and Gnathifera Volume 2, Nematoda: 435-465. De Gruyter, Hamburg.

Gambi C., Vanreusel A. \& Danovaro R. 2003. Biodiversity of nematode assemblages from deep-sea sediments of the Atacama Slope and Trench (South Pacific Ocean). Deep-Sea Research I 50: 103-117.

Gourbault N. \& Boucher G. 1981. Nématodes abyssaux (Campagne Walda du N/O “Jean Charcot”) III. Une sous-famille et six espèces nouvelles de Sphaerolaimidae. Bulletin du Museum national d'Histoire naturelle de Paris 4: 1035-1052.

Jacobs L.J. 1987. A redefinition of the genus Monhystrella Cobb (Nematoda, Monhysteridae) with keys to the species. Zoologica Scripta 16: 191-197. http://dx.doi.org/10.1111/j.1463-6409.1987.tb00066.x

Jensen P. 1992. Predatory nematodes from the deep sea: description of species from the Norwegian Sea, diversity of feeding types and geographical distribution. Cahiers de Biologie Marine 33: 1-23.

Leduc D. 2015. One new genus and five new nematode species (Monhysterida, Xyalidae) from Tonga and Kermadec Trenches, Southwest Pacific. Zootaxa 3964: 501-525. http://dx.doi.org/10.11646/ zootaxa.3964.5.1

Lorenzen S. 1981. Entwurf eines phylogenetischen Systems der freilebenden Nematoden. Veröffentlichungen des Instituts für Meeresforschung in Bremerhaven 7, Suppl., Institut für Meeresforschung, Bremerhaven.

Miljutin D.M., Gad G., Miljutina M.M., Mokievsky V.O., Fonseca-Genevois V. \& Esteves A.M. 2010. The state of knowledge on deep-sea nematode taxonomy: how many valid species are known down there? Marine Biodiversity 40: 143-159. http://dx.doi.org/10.1007/s12526-010-0041-4 
Somerfield P.J. \& Warwick R.M. 1996. Meiofauna in Marine Pollution Monitoring Programmes: a Laboratory Manual. Ministry of Agriculture, Fisheries and Food, Lowestoft.

Tietjen J.H. 1989. Ecology of deep-sea nematodes from the Puerto Rico Trench area and hatteras Abyssal Plain. Deep-Sea Research 36: 1579-1594. http://dx.doi.org/10.1016/0198-0149(89)90059-9

Vanhove S., Vermeeren H. \& Vanreusel A. 2004. Meiofauna towards the South Sandwich Trench (7506300 m), focus on nematodes. Deep-Sea Research II 51: 1665-1687.

Yoder M., Tandingan De Ley I., King I.W., Mundo-Campo M., Mann J., Blaxter M., Poiras L. \& De Ley P. 2006. DESS: a versatile solution for preserving morphology and extractable DNA for nematodes. Nematology 8: 367-376. http://dx.doi.org/10.1163/156854106778493448

Manuscript received: 9 September 2015

Manuscript accepted: 14 October 2015

Published on: 3 December 2015

Topic editor: Rudy Jocqué

Desk editor: Kristiaan Hoedemakers

Printed versions of all papers are also deposited in the libraries of the institutes that are members of the EJT consortium: Muséum national d'Histoire naturelle, Paris, France; Botanic Garden Meise, Belgium; Royal Museum for Central Africa, Tervuren, Belgium; Natural History Museum, London, United Kingdom; Royal Belgian Institute of Natural Sciences, Brussels, Belgium; Natural History Museum of Denmark, Copenhagen, Denmark. 